Hume, I. D. 1982 Digestion and Protein Metabolism Pada Manual in Nutrition and Growth. Published by AUIDP and AAUCS, 39.

Maria-Astuti. 1981. Rancangan Percobaan dan Analisa Statistik. Bagian II (Randomized Complete Block Designs, Repeated Measurement and Split-plot Designs). Bagian Pemuliaan Ternak Fakultas Peternakan UGM.

Martoatmodjo, R. S., I. Hamid dan Socmartono. 1983. Gamal Pohon Serba Guna. Balai Pustaka. Jakarta.

Nourusis, M. J. 1984. SPSS/PC. for the IBM PC/XT Original SPSS, Inc. Illinois
NRC 1978. Nutrient Requirements of Dairy Cattle. Nutrient Requirements of domestic Animals. $5 \mathrm{th}$ Revised ed. NAS. Washington DC.

Utomo, R. 1987. Pendugaan Total Nutrien Tercerna dan Energi Tercerna Bahan Pakan Berdasarkan Bahan Organik yang Tercerna. Laporan Penelitian. 05187. Fak. Peternakan Univ. Gadjah Mada.

Van Soest. P. J. 1982 Nutritional Ecology of the Rument. Published and Distributed by : $\mathrm{O}$ and Books Inc. Corvallis Origon, USA.

\title{
KINETIKA FERMENTASI D-GLUKOSA OLEH BACILLUS MACERANS : 1. ANALISIS ENSIM DALAM PROSES PEMBENTUKAN ASETAT, ASETON DAN ETANOL
}

\author{
Zaenal Bachrudin *)
}

\section{INTISARI}

Penelitian ini merupakan bagian dari proses perubahan selulose menjadi beberapa senyawa yang mempunyai nilai tambah atas jasa mikroorganisme. Proses ini sering disebut sebagai proses gabungan antara proses sakarifikasi dan proses fermentasi.

Bacillus macerans termasuk fakultatif anacrob bakteri, mampu tumbuh pada beberapa macam substrat, termasuk amilum, hemiselulose, glukose, dan xylose.

*) Staf pengajar pada Lab. Biokimia dan Nutrisi Fakultas Peternakan UGM
Pada $\mathrm{pH}$ medium 6.0 , fermentasi glukose oleh $B$. macerans ditandai dengan dua fase; fase acidogenic dan fase solventogenic. Perubahan fase tersebut diikuti dengan perubahan pada skala ensimatik. Ensim pembentuk asam asetat mempunyai aktivitas tinggi pada fase pertama, sedangkan ensim pembentuk aseton dan etanol aktif pada fase kedua. Pada $\mathrm{pH}$ medium 7.0 , proses fermentasi d-glukose oleh B.macerans ditandai dengan produksi sel yang mempunyai aktivitas ensim pembentuk asam asetat pada level yang tinggi.

Berdasarkan data yang diperoleh, dapat diambil kesimpulan bahwa, ensim thiolase merupakan ensim yang penting dalam pengaturan proses pembentukan aseton olch bakteri B.macerants.

(1) 
(Kata kunci : Kinetika fermentasi, D-Glukose, Bacillus macerans. Ensim, Asetat, Aseton, Etanol).

\section{TIIE KINETIC FERMENTATION OF D-GLUCOSE BY BACILLUS MACERANS: 1. LEVEL OF ENZYMES INVOLVED IN ACETATE, ACETONE AND ETHANOL FORMATION}

\section{ABSTRACT}

This study was a part of the direct bioconversion of cellulose to microbial products is often called a simultaneous saccharification and fermentation.

Bacillus macerans is a facultative anaerob. it grows on a wide variety of carbohydrates, including starch, hemicellulose, glucose, and xylose.

The fermentation of d-glucose by B.macerans at $\mathrm{pH} 6.0$, was characterisized by two distinct metabolic phase: acidogenic phase and solventogenic phase. The shift in metabolic activity when cells switch from acidogenic to solventogenic has been shown to be accompanied by a corresponding shift in the activity of the enzymes associated with acid and solvent producing pathways. However, the fermentation of d-glucose by B.macerans at $\mathrm{pH} 7.0$ was characterisized that the level enzymes involved in acetate formation have been shown at high activity.

The finding together with the data obtained from fermentation indicate that thiolase may be the key enzyme in the regulation of solventogenesis in this organism.

(Key Words: Cellulose, Biocon version, Fermentation, B.macerans, Asetate, Asetone, and Ethanol).

\section{PENDAHULUAN}

Banyak usaha telah dilakukan untuk memanfaatkan bahan limbah yang kaya akan selulose sebagai bahan pakan ternak atau sebagai sumber gizi (substrat) dalam proses fermentasi yang mampu menghasilkan produk yang mempunyai nilai tambah, misalnya, asam amino, vitamin, asam organik, dan larutan solven (aseton, dan etanol) (Asenjo et al, 1991). Salah satunya adalah proses secara simultan antara proses ensimatik dan proses biologik, seperti terlihat pada gambar 1 .
Substrat

(lignocellulose)

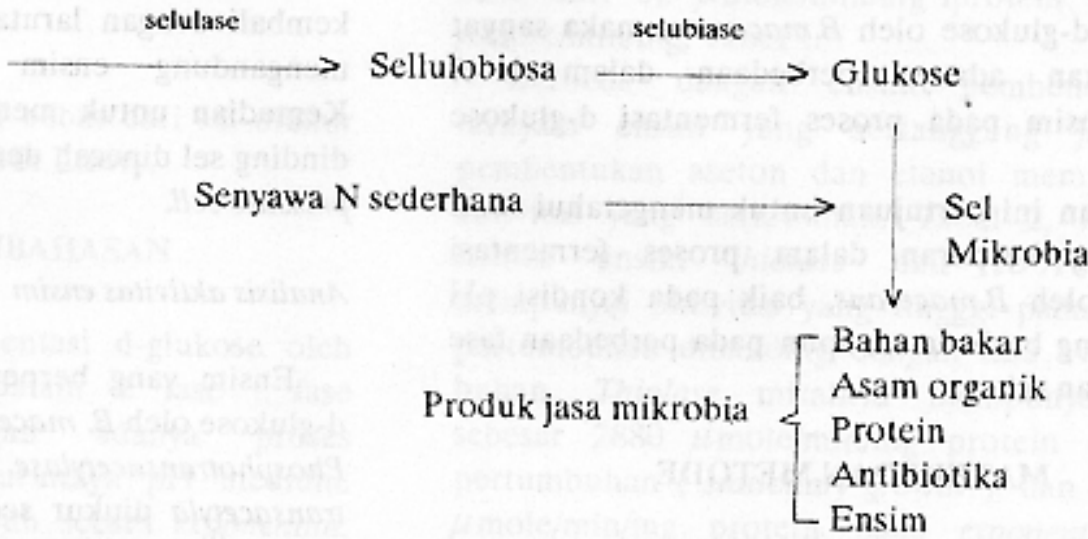

Gambar 1: Proses perubahan lignocellulosic menjadi beberapa produk secara simultan antara reaksi ensimatik dan reaksi biologik (Asenjo et al., 1991.) 
Dalam proses hidrolisis selulose dan hemiselulose, yang merupakan komponen utama limbah pertanian, akan menghasilkan beberapa campuran gula, misalnya d-glukose dan xylose sebagai produk utama (Lynch, 1987).

B.macerans, salah satu fakultatif bakteri anaerob yang mampu mengubah d-glukose menjadi senyawa asetat, aseton dan etanol melalui proses glikolisis dan heterofermentasi. Adapun tipe fermentasi d-glukose oleh B.macerans ditandai adanya dua fase: fase pertama merupakan fase pembentukan asam, dengan diikuti oleh turunnya $\mathrm{pH}$ serta sel tumbuh secara exponential. Fase kedua disebut fase pembentukan solven, terjadi kenaikan $\mathrm{pH}$, karena sebagaian asetat diubah menjadi aseton. Karena ketersediaan bahan dalam medium terbatas serta adanya produk yang bersifat toksik, maka sel akan mengalami pertumbuhan yang tetap, yang akhirnya akan berhenti (Wcimer, 1985; Schepers et al., 1986).

Disamping fase pertumbuhan mempengaruhi produk yang dihasilkan, ternyata $\mathrm{pH}$ medium juga mempengaruhi tipe produk yang dihasilkan dari proses fermentasi d-glukose oleh B.maserans. Pada $\mathrm{pH} 6.0$, akhir dari proses fermentasinya ditandai dengan pertumbuhan sel yang mampu menghasilkan solven, sedangkan pada $\mathrm{pH} 7.0$, asam asetat merupakan produk utama dari proses fermentasi d-glukose.

Sebagai konsekuensi dari pengaruh $\mathrm{pH}$ serta perbedaan fase pertumbuhan terhadap tipe fermentasi d-glukose oleh B.macerans, maka sangat dimungkinkan adanya perbedaan dalam level aktivitas ensim pada proses fermentasi d-glukose tersebut.

Penelitian ini bertujuan untuk mengetahui level ensim yang berperan dalam proses fermentasi d-glukose oleh B.macerans, baik pada kondisi $\mathrm{pH}$ medium yang berbeda maupun pada perbedaan fase pertumbuhan sel.

\section{MATERI DAN METODE}

\section{Mikroorganisme dan kondisi kultur}

Mikroorganisme yang digunakan dalam penelitian ini adalah Bacillus macerans NCTC. 1068, fakultatif bakteri. Medium yang digunakan mempunyai komposisi sebagai berikut : dalam satu liter, $\mathrm{K}_{2} \mathrm{HPO}_{4}, 30 \mathrm{~g}$; $\mathrm{NH}_{4} \mathrm{CL}, 2,50 \mathrm{~g} ; \mathrm{MgSO}_{4}, 0,20 \mathrm{~g}$; Glukose, $50,0 \mathrm{~g}$; yeast extract $2,0 \mathrm{~g}$; dan larutan mineral $10 \mathrm{ml}$ (Lovitt et al., 1987).

\section{Penyediaan sel}

Sel yang digunakan untuk analisis aktifitas ensim diperoleh dari batch fermentasi oleh B.macerans yang ditumbuhkan pada medium yang mengandung $5.0 \%$ (w/v) glukose dan $0,2 \%$ (w/v) yeast extract. Sampel sel yang diambil selain dari batch kultur dengan perbedaan fase pertumbuhan ( fase exponential dan fase stationary) juga dari batch kultur dengan perbedaan $\mathrm{pH}$ medium, pada $\mathrm{pH}$ 6,0 dan $\mathrm{pH} 7,0$.

\section{Persiapan larutan ensim}

Kira-kira sebanyak satu liter sel sebagai hasil fermentasi d-glukose oleh B.macerans, dipusingkan dengan sentrifuge pada suhu rendah, dengan kecepatan $15.000 \mathrm{~g}$ selama 15 menit. Endapan yang berbentuk kemudian dicuci dengan $0,1 \mathrm{M}$ fosfat buffer $\mathrm{pH}$ 7.40. Sebelum sel dalam bentuk pelet disimpan pada suhu rendah $(-4 c)$, larutan sel dipusingkan kembali dengan kecepatan serta lama pemusingan yang sama.

Sebanyak 10 gram sel yang telah beku diencerkan kembali dengan larutan buffer fosfat $\mathrm{pH} 7.4$, yang mengandung ensim DNAase $(0,245 \mathrm{mg} / \mathrm{ml})$. Kemudian untuk memperoleh ensim intrasellular, dinding sel dipecah dengan menggunakan alat french pressure cell.

\section{Analisis aktivitas ensim}

Ensim yang berperan dalam proses fermentasi d-glukose oleh B. macerans adalah :

Phosphotransacetylase : aktivitas ensim phosphotransacetyla diukur secara spektophoto-meter pada suhu $25^{\circ} \mathrm{C}$, dengan mengukur kadar Coensim-A yang dibebaskan karena adanya penambahan Acetyl co-A sebagai substrat (Andersch et al., 1983).

Coensim-A transferase : pengukuran ensim coensim $A$ transferase ditentukan dengan pengukuran tidak 
langsung. Acetyl co-A yang terbentuk akan mengalami proses pembebasan $C o-A$ dengan adanya ensim phosphotrasacetylase dan arsenat. $C o-A$ yang dibebaskan akan ditentukan dengan DTNB ( $5.5^{\prime}$ dithiobis (2-nitro-benzoic acid)(Andersch et al., 1983). Acetatkinase : aktivitas ensim acetatekinase ditentukan dengan mengukur kecepatan terbentuknya senyawa ADP karena adanya pyruvatekinase dan lactatdehidrogenase (Andersch et al.,1983).

Thiolase : ensim thiolase ditentukan berdasarkan reaksi thiolitik dimana acetoacetyl co-A sebagai substrat. Aktivitas ensim tersebut diukur dengan memonitor penurunan $\mathrm{Co}-\mathrm{A}$ pada panjang gelombang $303 \mathrm{~nm}$ ( Showkowski dan Hatrmanis.,1984 ). Glyceral dehyde-3-phosphodehydrogenase : metode yang dilakukan untuk analisis ensim tersebut didasarkan metode yang dilakukan olch Lovitt et al, 1988 ).

Hidrogenase : pengukuran ensim hidrogenase dilakukan pada kondisi anaerob. Aktivitas ensim tersebut dilakukan dengan memonitor reaksi reduksi dari methil viologen.

Pyruvat dehydrogenase : penentuan ensim pyruvate dehydrogenase pada dasarnya sama dengan pengukuran ensim hydrogenase.

Acetaldehyde reductase dan ethanol dehydrogenase: metode pengukuran kedua ensim tersebut meng gunakan metode yang dilakukan oleh Lovitt et al., 1988 ).

\section{Analisis kadar protein}

Protein sampel yang telah bebas dari sel diukur kadar proteinnya dengan metode Lowry.

\section{HASIL DAN PEMBAHASAN}

Sesuai dengan tipe fermentasi d-glukose olch B.macerans, yang terbagi dalam 2 fase : fase acidogenic ditandai dengan adanya proses pembentukan asetat serta turunnya $\mathrm{pH}$ medium. Pada fase ini pula sel tumbuh secara exponential. Fase yang kedua adalah fase solventogenic. Pada fase ini sel memanfaatkan sisa glukose yang tersedia, serta senyawa asetat yang terbentuk untuk disentesis menjadi aseton dan etanol.
Hasil dari proses fermentasi secara batch kultur, menunjukkan bahwa $\mathrm{pH}$ medium sangat berhubungan dengan produk yang dihasilkan. Batch fermentasi pada $\mathrm{pH}$ 6,0 akan menunjukan bahwa sel mampu memproduksi aseton pada kadar yang lebih tinggi dibandingkan pada $\mathrm{pH} 7,0$. Pada $\mathrm{pH} 7,0$ tipe proses fermentasi d-glukose ditandai dengan produksi asetat pada konsentrasi yang tinggi.

Dengan dasar hal tersebut diatas, maka secara garis besar ensim yang berperan dalam proses fermentasi d-glukose oleh B.macerans dibagi menjadi 3 kelompok : i) ensim yang berperan dalam proses glikolisis, ii) ensim yang memproduksi asam asetat, iii) ensim yang mampu menghasilakn aseton dan etanol.

\section{A. Aktivitas ensim karena perbedaan fase pertumbuhan sel}

Dari hasil analisis aktivitas ensim karena perbedaan fase pertumbuhan ( fase exponential dan fase stationary, menunjukkan bahwa ensim acetatekinase dan phosphorransacetylase pada fase pertumbuhan awal mempunyai aktivitas yang tinggi daripada fase akhir pertumbuhan. Aktivitas ensim phosphotransacetylase terjadi penurunan kira-kira sebesar $50 \%$ dari $540 \mu \mathrm{mole} / \mathrm{min} / \mathrm{mg}$ protein pada awal pertumbuhan menjadi $250 \mu \mathrm{mole} / \mathrm{min} / \mathrm{mg}$ protein pada akhir pertumbuhan, sedangkan asetatkinase aktivitasnya menurun hanya sebesar $20 \%$ dari $52 \mu \mathrm{mole} / \mathrm{min} / \mathrm{mg}$ protein menjadi 43 $\mu \mathrm{mole} / \mathrm{min} / \mathrm{mg}$, Tabel 1.

Berbeda dengan ensim pembentuk asetat, ternyata ensim yang bertanggung jawab pada pembentukan aseton dan etanol mempunyai tipe aktivitas yang berlawanan. Tabel 2, menunjukan bahwa ensim thiolase dan co-A transferase mempunyai aktivitas yang tingggi pada fase akhir pertumbuhan dibanding dengan fase awal pertumbuhan. Thiolase misalnya mempunyai aktivitas scbesar $2880 \mu \mathrm{mole} / \mathrm{min} / \mathrm{mg}$ protein pada akhir pertumbuhan (stationary growth), dan hanya 1120 $\mu \mathrm{mole} / \mathrm{min} / \mathrm{mg}$ protein pada exponential growth. Begitu juga terjadi pada ensim aceto acetyl co-A transferase secara berturut- turut mempunyai aktivitas sebesar 180 dan $50 \mu \mathrm{mole} / \mathrm{min} / \mathrm{mg}$ protein pada akhir dan awal pertumbuhan. 


\section{KESIMPULAN}

Seperti yang diharapkan dari penelitian ini, bahwa bila terjadi perubahan aktivitas metabolisme dari proses fermentasi d-glukose oleh B.macerans dari fase acidogenic manjadi solventogenic dengan ditunjukkan dari produk yang dihasilkan, ternyata dari data yang diperoleh, perubahan tersebut diikuti dengan perubahan aktivitas ensim yang berhubungan dengan proses pembentukan asam dan pembentukan solven.

Dari penelitian ini pula dapat disimpulkan bahwa besarnya aktivitas ensim yang mengkatalisis proses pembentukan asam dan solven merupakan fungsi baik dari fase pertumbuhan sel maupun $\mathrm{pH}$ medium.

\section{DAFTAR PUSTAKA}

Anderesch,W.,H. Bahl,and G. Gatschalk. 1983. Level of enzymes involved in acetate, butyrate, acetone and butanol fermentation by Clostridium acetobutylicum. Eur J. Appl. Microbiol. Biotechnol. 18:327-332.

Asenjo, L. A., W.H.Sun, and J. L. Spencer. 1991. Optimization of batch processes involving simultaneous enzimatic and microbial reactions. Biotechnol.Bioeng 37:1087-1094

Hartmanis, M. G. N., and S. Gatenbeck. 1984. Intermediary metabolism in Clostridium acetobutylicum : levels of enzymes involve in the formation of acetate and butyrate. Appl. Environ Microbiol 47:1277-1283

Lovitt, R. W., D. B. Kell, and J. G. Morris. 1987. The physiology of Clostridium sporogenes NCTB 8053 growing in defined media. J. Appl. Bacteriol 62:81-92.

Lovitt, R. W., G. J. Shen, and J. G. Zeikus. 1988. Ethanol production by thermophilic bacteria : Biochemical basis for ethanol and hydrogen tolerance in Clostridium thermohydro. sulfuricum. J. Bacteriol 170(6):2809-2815.

Lynch, J. M. 1987. Utilization of lignocellulosic waste J. Appl. Bacteriol. Symp. Suppl. 715-835.

Schepers, H. J., S. B. Meyer, and H. Sahm. 1086. Fermentation of D-xylose to ethanol by Bacillus macerans. $Z$. Naturforsch. $42 \mathrm{C}$ : 401-407.

Shiokowski, M. X., and M. G. M. Hartmanis, 1984. Simultaneous single-step purification of thiolase and NADP-dependent 3-hydroxybutyryl-co A dehydrogenase from Clostridiumkhuyveri Anal Biochem. 141 : 344-347.

Weimer, P. J. 1984. Control of product formation during glucose fermentation by Bacillus macerans. J. Gen. Microbial. 130:103-111 